Sílvia Portugal

Paulo Henrique Martins

Organização

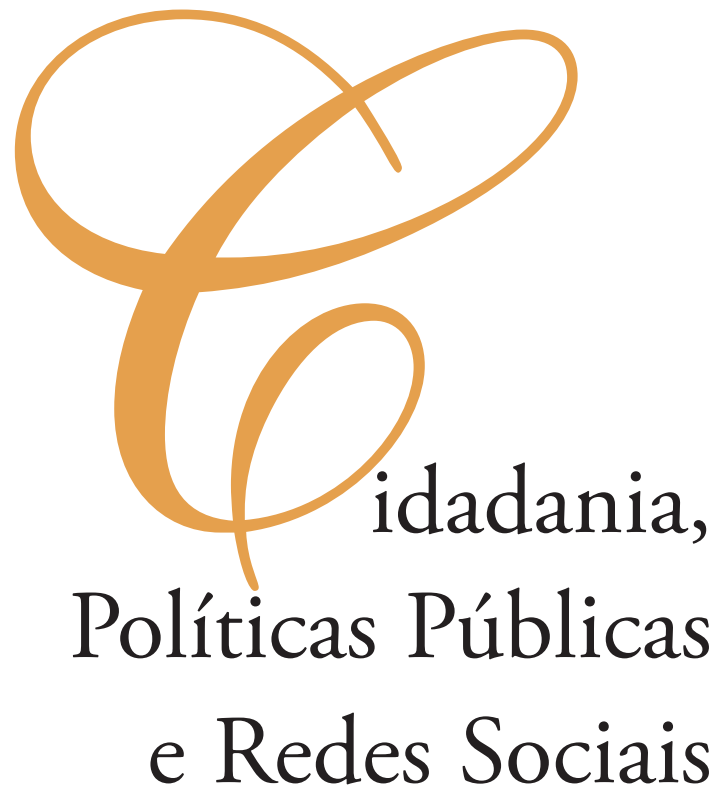


Sílvia Portugal

\section{Dádiva, Família e Redes Sociais}

\section{Introduçáo}

As teses sobre o processo de individualização nas sociedades modernas tendem a opôr um quadro passado de fortes laços e obrigaçóes familiares a um presente com um escasso peso das relaçôes e obrigaçôes familiares. Esta é uma visão "monocromática" da relação entre família e indivíduo (Smart e Shipman, 2004), que é preciso "colorir", repensando a natureza dos laços sociais que ligam o indivíduo à família. É este objectivo que me proponho cumprir neste capítulo. A reflexão que aqui apresento estrutura-se em torno de dois conceitos fundamentais: o conceito de dom e o conceito de rede social. Parto, assim, da discussão do estatuto da dádiva nas sociedades contemporâneas. A perenidade do sistema de dom tem sido ocultada por duas tendências hegemónicas: a das teorias utilitaristas, no pensamento académico, a do Estado, na protecção social. O sistema estatal tem um tipo específico de relação com o sistema de dom. Por um lado, muitos serviços anteriormente prestados pelas redes pessoais ou de caridade foram assumidos pelo Estado. Por outro lado, este (ao contrário do mercado) não nega o altruísmo: recebe, organiza, reparte e distribui em nome da solidariedade; solidariedade mais extensa do que a das redes primárias, mais justa do que a dos sistemas de caridade. O desenvolvimento do Estado-Providência foi, por esse motivo, visto como um substituto feliz do dom, diminuindo a injustiça e a desigualdade e repondo a dignidade dos beneficiados. Deste modo, alguns autores viram na providência estatal a forma moderna da dádiva, cujas formas tradicionais se tornariam cada vez mais residuais.

Neste texto pretendo contrariar estas perspectivas. Em primeiro lugar, defendo que sistema estatal e sistema de dádiva não são sinónimos e fundam-se em princípios diferentes. Em segundo lugar, procuro demonstrar a vitalidade do dom face às deficiências do sistema estatal. Partindo da hipótese central de que o espaço doméstico é o lugar de base do dom, o local onde ele é vivido com maior intensidade e onde é realizada a sua aprendizagem ${ }^{1}$, pretendo identificar, a partir da família, os vínculos sociais que alimentam o sistema de dádiva e analisar as lógicas que regem a sua acção.

Deste modo, o conceito de rede social surge como um conceito operacional que permite analisar, simultaneamente, a forma e o conteúdo das relaçóes sociais envolvidas na

1 Sobre as características do espaço doméstico como espaço estruturante das relaçôes sociais cf. Santos (1994 e 2000). 
produção de bem-estar. A abordagem a partir da network analysis possibilita a passagem do nível macro ao nível micro, das estruturas sociais à acção individual, ou seja, no caso, permite discutir o modo como se articulam sistemas de produção de bem-estar e condiçóes individuais.

A reflexão que aqui apresento tem por base uma pesquisa empírica, de carácter qualitativo, que estudou o papel das redes sociais das famílias no acesso aos recursos de bem-estar. Foram realizadas 60 entrevistas em profundidade a pessoas com idades entre os 25 e os 34 anos, vivendo em situação de conjugalidade, com ou sem filhos.

Qual o papel que cabe à família na produção de bem-estar? Qual o papel das redes sociais na provisão de recursos? Quais são os laços mais activos das redes? Que tipo de necessidades permitem suprir? Qual o papel dos laços de parentesco? Como se articulam as redes informais com outros modos de produção de bem-estar? O que as faz mover? Quais são as normas que regulam a sua acção? Estas foram algumas das questôes às quais a pesquisa procurou dar resposta.

O estudo reconstituiu as redes de relaçóes da família a partir de uma abordagem "egocentrada", ou seja, identificando os indivíduos que interagem com um determinado "alvo" (indivíduo ou casal) (Milardo, 1988). Este tipo de procedimento tem a vantagem de nos dar uma visão ptolomeica das redes: em vez da concepção do observador exterior obtem-se a perspectiva dos indivíduos que se encontram no seu centro. No entanto, um dos problemas das redes egocentradas consiste na dificuldade em identificar a totalidade dos membros da rede de um dado indivíduo ou família, sendo quase sempre necessário criar uma amostra do total da sua população. A pesquisa utilizou três abordagens diferenciadas para reconstituir as redes sociais: as redes de intímos ${ }^{2}$, as redes de interacção ${ }^{3}$ e as redes de troca ${ }^{4}$. Utilizando estes três procedimentos, em simultâneo, identificam-se os elementos significativos, do ponto de vista simbólico, ao mesmo tempo que se confrontam as pessoas com uma série de cenários sociais de modo a identificar os indivíduos com os quais existe interacção e trocas efectivas. Cruzam-se, assim as decisóes do/a entrevistado/a e da investigadora sobre quem deve ser incluído na rede, procurando-se, por um lado, uma aproximação à totalidade da rede social e, por outro lado, uma inclusão de diferentes tipos de laços.

Da análise realizada (Portugal, 2006) destaco algumas das conclusôes, que de seguida utilizarei para discutir a relação entre dádiva, família e redes sociais: a centralidade das redes sociais na provisão de recursos às famílias; a diferenciação dos laços activados e da morfologia das redes consoante o recurso que está em jogo; o familismo das redes sociais; a permanência e vitalidade da dádiva e a sua importância na produção de bem-estar das famílias; a complexidade do sistema de normas que regula o dom familiar.

2 As redes de intímos são constituídas pelos indivíduos considerados importantes pelo "alvo". Milardo define, operacionalmente, este tipo de redes como "indivíduos cuja opinião acerca da sua vida pessoal é importante para si" (Milardo,1988: 22).

3 As redes de interacção são constituídas pelos indivíduos com quem "ego" interage numa base de rotina.

4 As redes de troca incluem os indivíduos com os quais a probabilidade de recompensa de trocas é elevada. Este tipo de abordagem "inclui entre os membros da rede social as pessoas cujo comportamento recompensa ou penaliza ego ou as pessoas que são directamente recompensadas ou penalizadas por ego" (Fischer, 1982: 287). As trocas incluem um vasto leque de interacçóes, avaliadas quer positiva quer negativamente, que vão desde a ajuda material e a prestação de serviços, ao aconselhamento e companhia nas actividades de lazer. 


\section{Os nós e os laços}

Quem faz parte da rede? Com quem se estabelecem as trocas? Com quem se interage? Com quem se pode contar? A quem se recorre quando se precisa de emprego? A quem se deixam as crianças? A quem se pede dinheiro emprestado? A quem se contam os segredos? Para uns, as respostas a estas e outras questôes permitem identificar múltiplas relações, para outros, com diferentes perguntas obtêm-se sempre os mesmos nomes. No entanto, apesar da diversidade na morfologia das redes que foi possível encontrar, é importante sublinhar algumas características transversais que emergem na análise da identificação dos nós da rede: a primeira, prende-se com a clara distinção entre as relaçóes de parentesco e as restantes relaçôes sociais - existe a família e existem "os outros". Os laços familiares representam segurança, permanência, confiança. Por oposição, os "outros" laços estabelecidos fora do parentesco são muitas vezes alvo de desconfiança e insegurança, os relatos de desilusóes com amigos e vizinhos são muito mais frequentes do que aqueles que se referem aos parentes.

A divisão entre "a família" e "os outros" tem duas implicaçōes: por um lado, é nos laços familiares que a maioria das pessoas encontra resposta para as suas necessidades de apoio material e afectivo. Por isso, quando alguém fora das relaçóes familiares é um nó importante da rede, um amigo próximo, um colega com quem se pode contar, essa pessoa "é como se fosse da família". Por outro lado, os nós que pertencem à rede familiar tendem também a assumir a representação de um "nós" - um colectivo de pertença e de referência. Cada família dispóe de um certo número de atributos e de referências identitárias que funcionam como símbolos de reconhecimento e diferenciação social a partir dos quais se situa a identidade singular do indivíduo. O conjunto destes elementos fornece uma espécie de carta comum a todos os membros do grupo familiar cujo código é transmitido, negociado, apropriado e reapropriado, construindo ao longo do tempo a identidade familiar e definindo, a partir de uma mesma trama colectiva, a identidade pessoal de cada um. Deste modo, os laços familiares apresentam-se como um todo com identidade própria, que representa uma esfera de identificação e referência, que dificilmente se encontra para a totalidade da rede ou para outros conjuntos de relaçôes (os amigos, os colegas, os vizinhos) - "nós somos assim", "connosco nunca há problemas", "na nossa família estamos habituados a fazer desta maneira”.

A segunda característica que emerge na identificação dos nós da rede é a sua tendência para a homogeneidade social. As redes heterogéneas são menos comuns do que as homogéneas. Os elementos da rede são da mesma família, ou da mesma vizinhança, ou do mesmo grupo socioprofissional, ou têm o mesmo nível educacional. Fora da rede de parentesco, os nós da rede apresentam características socioeconómicas e socioculturais muito semelhantes. De um modo geral, as redes apresentam uma forte tendência para a homofilia (Degenne e Forsé, 1994: 43-46; Lin, 2001: 38-40), sobretudo entre as mulheres, como sublinharam Lynn Smith-Lovin e J. Miller McPherson (1993).

Longe de se construírem de uma forma socialmente aleatória, as redes de relaçóes pessoais são nitidamente marcadas pelas características estruturais de quem as compóe e, em grande parte, socialmente pré-determinadas. Se esta realidade é mais ou menos óbvia para as relaçóes de parentesco, ela continua a revelar-se nas relaçóes de afinidade. As relaçóes com amigos, colegas e vizinhos são fortemente marcadas pela homofilia, sobretudo ao nível dos estatutos socioculturais mais elevados. Se, do ponto de vista do estatuto profissional, as redes são mais heterogéneas, do ponto de vista da escolaridade os diplomas de ensino 
superior marcam a diferença: entre os licenciados a homofilia das redes de afinidade é quase absoluta .

A pesquisa que realizei permite responder afirmativamente à questão colocada por Alexis Ferrand sobre se as relaçóes familiares formam um subsistema autónomo no conjunto de relaçóes do indivíduo (Ferrand, 1992). Os parentes são os nós predominantes na maioria das redes analisadas, quer se trate de trocas, de interacção ou de significado emocional. A maioria dos laços fortes é constituída no interior das relaçóes familiares e caracteriza-se pela multiplexidade e pela transitividade. Deste modo, os parentes constituem um subsistema, fortemente interligado, no interior das redes sociais.

No entanto, se olharmos para as três relaçóes elementares fundadoras do parentesco a relação de aliança, a relação de consanguinidade e a relação de filiação (Lévi-Strauss, 1949) - verificamos que os laços gerados por cada uma delas têm funçóes diferenciadas e diferenciadoras no interior da rede. Quer de um ponto de vista material, quer emocional, os laços de filiação são com grande frequência os mais fortes, seguindo-se os laços de consanguinidade. Os nós que entram na rede por via do casamento têm, em geral, um estatuto secundário - mesmo que desempenhem um papel activo ao nível das trocas e da interacção; do ponto de vista emocional, os laços estabelecidos através da relação de aliança são secundarizados pelas pessoas entrevistadas ${ }^{6}$. Esta constatação é, no entanto, mais comum entre as mulheres do que entre os homens. As mulheres têm mais dificuldade em assumir a família do marido como sendo sua, do que o inverso.

A importância da rede de parentesco deve-se ao facto de ela oferecer "garantias" que não se encontram noutro tipo de relaçóes. Uma delas é a permanência no tempo: muitos dos laços estabelecidos fora da família - relaçóes com colegas de escola ou de trabalho, com vizinhos, com amigos - não resistem à passagem do tempo, que se sobrepóe a outro tipo de mudanças, como as geográficas. Existe um sentimento generalizado de que "com a família podemos sempre contar". Esta representação dos laços familiares resulta de um entrecruzar de vínculos biológicos, emocionais, sociais e jurídicos, socialmente construídos, simultaneamente, no interior e no exterior da família. A rede familiar representa para a maioria das pessoas entrevistadas uma rede de protecção e de segurança. Os parentes são um porto de abrigo ao qual se pode sempre recorrer - mesmo que os laços não estejam sempre activos na prestação de apoios, "eles estão sempre lá quando é preciso".

É de sublinhar que a importância dos parentes é significativa mesmo quando os laços não são positivos. As situaçôes de conflito e de ruptura das relaçôes familiares são sentidas com dor pelas pessoas que as revelam. Independentemente das causas, ser privado dos laços de parentesco representa uma perda profunda, sobretudo quando esses laços se estabelecem com base numa relação de filiaçáo ou de consanguinidade. As rupturas de relaçóes com

${ }^{5}$ Estes dados aproximam-se das conclusóes de Elísio Estanque e José Manuel Mendes sobre a permeabilidade das fronteiras de classe nas redes de amizade. Os autores concluem que a sociedade portuguesa apresenta uma "estrutura social relativamente rígida também na constituição das relaçóes de amizade, sendo as qualificaçóes a dimensão estruturadora das relações sociais de amizade” (Estanque e Mendes, 1998: 128).

${ }^{6}$ Estas conclusôes são consonantes com resultados de trabalhos anteriores. António Manuel Hespanha defende que a preferência dos laços generativos aos conjugais é uma das linhas estruturantes da família no Antigo Regime (Hespanha, 1993: 956). Brian O’Neill, ao estudar os padrōes de casamento em Trás-os-Montes, conclui que a residência natolocal não é unicamente resultado de uma falta de meios para construir casas, antes sugere uma ênfase cultural generalizada sobre a descendência e os vínculos de filiação em detrimento do casamento e dos laços de afinidade (O’Neill, 1984: 320-337). 
parentes que resultam da relação de aliança nunca são apresentadas de uma forma tão dramática, lamentam-se mais as perdas do cônjuge do que as próprias, o que vem mais uma vez confirmar a secundarização dos laços de parentesco estabelecidos através do casamento.

Na obra A corrosão do carácter, Richard Sennett (2001) analisa os novos tempos do trabalho e discute o modo como as instituiçôes modernas se sustentam em esquemas que privilegiam o curto prazo, limitando, deste modo, o fortalecimento da confiança informal. O mote é "não há longo prazo" - "um princípio que corrói a confiança, a lealdade e a entrega mútua" (Sennett, 2001: 37). O autor sublinha a desvalorização dos laços fortes e a importância dos laços fracos, num contexto de permanente mudança, onde o distanciamento e a cooperação superficial são mais benéficos do que a lealdade e o compromisso. Sennett identifica um conflito entre trabalho e família, esfera em que o compromisso mútuo e o longo prazo são fundamentais. Deste conflito, o autor extrai algumas questôes sobre a "experiência adulta": como se procuram objectivos de longo prazo numa sociedade de curto prazo? Como se podem manter relaçóes sociais duradouras? Como pode um ser humano desenvolver uma narrativa de identidade e história de vida numa sociedade composta de episódios e fragmentos? (Sennett, 2001: 41).

O meu trabalho aponta para que a resposta a estas perguntas resida nos laços de parentesco. Como atrás se observou, uma das linhas que sustenta a força dos laços familiares é a perenidade das relaçóes. O laço de parentesco oferece a perspectiva de longo prazo que falta às outras relaçôes, mais susceptíveis às mudanças de diferentes tipos e à erosão pelo tempo. É a permanência das relaçóes familiares, garantida pelo laço biológico, que permite, em larga medida, a construçáo da confiança e do compromisso mútuo que constituem âncoras instrumentais e afectivas para os indivíduos e as suas famílias. Deste modo, os laços de parentesco constituem-se como elementos estruturadores do desenho das redes sociais.

Coenen-Hunter et al. distinguem quatro tipos de laços de parentesco na sua análise das solidariedades familiares (1994: 352-361): a tendência para o desapego (détachement), o instrumentalismo, a expressividade e o familismo. O desapego caracteriza-se por um nível fraco de ajudas dadas e recebidas, a raridade dos encontros, uma distância afectiva dos parentes, uma fraca organização da rede, uma difusão restrita das solidariedades e uma confiança muito limitada no apoio prestado pelos familiares. $\mathrm{O}$ instrumentalismo caracteriza as famílias que ajudam os seus parentes em questóes concretas (guarda das crianças, trabalho doméstico). A proximidade afectiva é baixa, a frequência dos encontros decorre dos serviços prestados, a concentração geográfica da parentela é grande, não existe um sentimento de poder contar com as pessoas, nem se reconhece o dever de ter que as ajudar. A expressividade caracteriza um "género de relaçóes de parentesco menos claras" (p. 354): a proximidade afectiva é forte, existe um sentimento de poder contar com grande parte dos parentes e uma recusa de retribuição na prestação de apoio. No entanto, é possível pensar que estas características não passam de declaraçóes de boas intençóes, dado que a instrumentalidade é fraca (as ajudas dadas e recebidas são escassas). Os autores preferem, contudo, uma interpretação mais positiva: o estilo de relacionamento é muito expressivo, os sentimentos são fortes, mas não necessariamente acompanhados por possibilidades de se manifestar sob a forma de apoios concretos. Finalmente, o familismo caracteriza as famílias que gostam muito dos seus parentes e os encontram com frequência. As ajudas são intensas, sabe-se que se pode contar com os parentes e está-se disposto a ajudá-los quando é necessário. A ajuda mútua assenta em normas explícitas de solidariedade que reforçam a tendência para ajudar ligada às proximidades afectivas. 
Embora a metodologia utilizada por estes autores seja muito diferente da do meu estudo ${ }^{7}$, a tipologia e a caracterização dos laços de parentesco que apresenta parecem-me bastante pertinentes para analisar os dados da pesquisa que aqui apresento, não apenas pela suas potencialidades analíticas, mas também pela possibilidade de confrontar resultados. Analisando as propriedades dos laços de parentesco verificamos, que, em geral, esses laços são laços fortes e positivos, circula no seu interior uma grande diversidade de recursos, os contactos e trocas são intensos, existe uma interacção frequente, a influência e a interferência dos parentes, sobretudo dos ascendentes, na vida da família conjugal é significativa. As entrevistas revelam que para a maioria das famílias os laços de parentesco se definem pelo familismo, contrariando as conclusóes do estudo de Coenen-Hunter et al., no qual se afirma que o "familismo é nitidamente minoritário" (1984: 355). Ao contrário, a tendência para o desapego que preocupa os autores pela sua relevância estatística - duas famílias em cada cinco (idem: 353), é minoritária no meu estudo. Aqueles que conjugam uma baixa frequência de contactos e de ajudas com um afastamento emocional dos familiares são a excepção. Apesar dos resultados não serem comparáveis de um ponto de vista estatístico, as entrevistas permitem apontar para a existência de uma realidade social bastante distinta da descrita pelos autores para a Suíça ${ }^{8}$. A minha pesquisa mostra a importância crucial dos laços de parentesco, quer do ponto de vista instrumental, quer do ponto de vista afectivo - o parentesco é um laço determinante na configuração das redes sociais dos indivíduos e das suas famílias.

O discurso de uma das entrevistadas, expressa bem as características deste familismo, simultaneamente, instrumental e expressivo, que preenche necessidades materiais e afectivas: "Posso contar com a minha família toda... toda... o meu marido, o meu filho, os meus pais, a minha irmã, a minha sogra... são as pessoas que eu... eu sei que posso contar sempre com eles, sempre. Sei que é uma coisa incondicional. Ninguém póe condiçóes para ajudar quem gosta e eles também sabem que podem contar sempre comigo."

O familismo que caracteriza as redes sociais é alimentado por intensas relaçóes intergeracionais, uma forte matrilinearidade e uma nítida lateralização do lado da mulher. Estas três características resultam de uma complexidade de elementos: consaguinidade, afectos, apoios, sociabilidade, direitos legais, obrigaçóes morais, modos de ser, de fazer e de pensar que se constroem no tempo longo da continuidade geracional que a família garante. Até certo ponto este familismo desempenha um papel excludente face a outro tipo de relaçóes sociais, mas não apresenta as características do "familismo amoral" de que fala Edward Banfield $(1967)^{9}$. As redes sociais são marcadas pelo familismo, mas este não assume o carácter negativo que lhe confere este autor, mas, antes, um sentido positivo, desempenhando um

${ }^{7}$ A tipologia apresentada foi construída a partir de dados quantitativos recolhidos através de um inquérito por questionário e tratados estatisticamente através de uma análise de clusters (Coenen-Hunter et al., 1994: 350-352).

${ }^{8}$ Neste sentido apontam, também, outras análises relativas ao "modelo do Sul", em que se destaca o papel da família nos sistemas de protecção social de Portugal, Espanha, Itália e Grécia (Andreotti et al., 2001).

9 Edward Banfield usou o conceito "familismo amoral" para descrever as práticas dos camponeses do Sul da Itália na década de 50, caracterizando "as bases morais de uma sociedade atrasada”. Segundo o autor, estas eram explicadas pela incapacidade dos indivíduos agirem colectivamente em função de um bem comum ou de qualquer fim que transcendesse o interesse material e imediato da família nuclear. Esta incapacidade para concertar qualquer actividade para além da família imediata derivava de um ethos - o "familismo amoral" - produzido por três factores agindo em combinação: a elevada taxa de mortalidade, as condiçóes relativas à propriedade da terra e a ausência da família alargada. 
papel de recurso estratégico no plano da protecção pessoal e familiar, tal como defende Manuel Villaverde Cabral (2005).

Recentemente, este autor recuperou as ideias de Banfield para discutir o problema da "distância ao poder" da sociedade portuguesa (Cabral, 2005). Villaverde Cabral dissocia o conceito da exclusiva esfera económica e transporta-o para a dimensão social, nas suas articulaçôes com o Estado e o poder político. O autor identifica "dois grandes nexos históricos de longa duração" que se terão constituído como elos mediadores entre o "familismo amoral" e a "distância ao poder": a literacia e o despotismo administrativo do Estado português moderno. Estes dois factores constituem dois nexos estruturantes das relaçôes entre as elites do poder e as classes subordinadas, que têm contribuído para reproduzir a falta de confiança e de participação da maioria da população nas instituiçôes representativas. Articuladas entre si, estas duas formas de relacionamento comunicacional e político entre elites e massas terão gerado uma forma duradoura de dominação autoritária, de modo que, nem a liberalização do sistema político-partidário, nem a massificação do ensino, nem o crescimento económico conseguiram erradicar das representaçóes e práticas da maioria da população portuguesa um sentimento generalizado de "distância ao poder" (Cabral, 2005: 21).

Da reconstrução que o autor faz do conceito de Banfield dois traços revelam-se bastante interessantes para a presente discussão: por um lado, o "familismo amoral" é recuperado como forma de identificar um conjunto de representaçóes e práticas que favorece, no seu relacionamento externo, nomeadamente com o Estado e o mercado de trabalho, o estabelecimento de relaçóes verticais assimétricas (dependência clientelar) em detrimento de relaçóes horizontais organizadas e estáveis, nomeadamente de participação cívica, de associativismo e mobilizaçáo colectiva, em suma, os dispositivos convencionais do exercício dos direitos de cidadania. Por outro lado, Villaverde Cabral desconstrói a negatividade do conceito, sublinhando o seu carácter de recurso estratégico (de que o clientelismo faz parte integrante) no plano da protecção pessoal e familiar e no plano das relaçóes com o sistema político ${ }^{10}$.

Parto destes contributos para me interrogar sobre o carácter do familismo no nosso país. Procuro avaliar o seu impacto na configuração das relaçóes sociais e na relação entre público e privado. O familismo é uma causa para o afastamento dos indivíduos da esfera colectiva, como afirma Banfield, ou antes um mecanismo de defesa perante um Estado autoritário e deficitário em políticas sociais? Se o quisermos adjectivar, teremos, contrariando Banfield, que o designar como "familismo moral", dado que a sua acção é pautada por normas de obrigação e reciprocidade, como se verá de seguida.

\section{As normas ${ }^{11}$}

Por que é que uma pessoa ajuda a outra? Por que é que uma pessoa recebe ajudas de outra? Que expectativas têm dadores e receptores? Que normas regulam as trocas no interior das redes? O que é considerado certo e errado, justo e injusto? Como se definem as obrigaçóes? Laços diferentes obedecem a princípios diferentes?

10 Os trabalhos de Fernando Ruivo sobre as relaçóes entre poder central e local têm mostrado com clareza o modo como as relaçôes informais são um recurso fundamental no sistema político português (Ruivo, 2000).

11 Retomo, neste ponto, argumentos aprofundados em Portugal (2007). 
A pesquisa aponta para uma resposta afirmativa a esta última questáo, condicionando, assim, em grande parte, as respostas às restantes questóes. As normas que regulam a interacção no interior das redes dependem do tipo de laço que está em jogo. O que está certo ou errado, o que é devido ou não, o que é justo ou injusto depende da natureza da relação em causa. As normas reflectem uma relação entre as pessoas mais do que um equilíbrio entre coisas trocadas. Como concluem Kellerhals et al. (1995), o sentimento de justiça traduz, em primeiro lugar um projecto relacional, um "reconhecimento das pessoas".

Os trabalhos de Jean Kellerhals e dos seus colaboradores sobre os critérios que regulam a justiça distributiva (quem tem direito a quê?) e processual (como chegar a decisôes justas?) têm feito escola. No seu livro Figures de l'équité. La construction des normes de justice dans les groupes (Kellerhals et al.,1988), os autores identificam cinco questóes genéricas que estruturam a definição de justiça nos grupos: uma primeira decisão diz respeito à norma de repartiçâo: que regra utilizar para distribuir os bens raros? A necessidade, o mérito, a igualdade ou ainda outro critério? Mas colocar este princípio em acção implica a intervenção de normas de avaliação, ou seja, de critérios que permitam definir o valor das contribuiçóes e a situação dos membros do grupo que participam na troca. Em terceiro lugar, a norma de comparação define a forma como o estatuto e a identidade social são importantes para a decisão interna de justiça: estas categorias são ignoradas ou, pelo contrário, tão importantes que as normas de repartição e avaliação funcionam em função delas? Qualquer destas opçóes pode ser afectada pela natureza do bem em jogo. Trata-se de aplicar uma regra de transformação: pode-se ou não utilizar as mesmas regras e os mesmos critérios para distribuir bens de natureza diferente?

Finalmente, os autores sublinham que estes quatro aspectos da decisão de justiça estão condicionados pelo problema da norma de apropriaçáo. Trata-se de saber como o grupo constitui a massa de bens sobre os quais posteriormente procede a uma repartição. A norma de apropriação define se os títulos de propriedade individual que prevalecem fora do grupo são conservados no seu interior ou se, pelo contrário, o grupo define a todo o momento os direitos de propriedade dos seus membros. No primeiro caso, o indivíduo define as fronteiras do grupo, no segundo caso é o inverso que acontece.

A pesquisa permite concluir que a aplicação destes critérios, ao conjunto da rede, depende da natureza e da força dos laços e também do recurso em jogo. Ou seja, as normas de comparação (qual é o laço da rede) e de transformação (qual é o bem em causa) prevalecem sobre a norma de repartição. Por um lado, os critérios que definem a justiça entre contribuiçôes e retribuiçóes aplicam-se de forma diferente, dentro e fora da rede de parentesco. Como afirma Alexis Ferrand, "a grandeza, por vezes, o horror, dos laços familiares está na capacidade de decretar a equivalência de valor entre ajudas totalmente heterógeneas" (Ferrand, 1992: 89). Por outro lado, o tipo de bem em jogo obriga a rever a aplicação das normas. Bens de natureza diferente obrigam a critérios diferentes, dentro e fora da família. Se os pais têm mais do que um filho e fazem uma doação de dinheiro a um, a norma que prevalece é a da igualdade - todos devem receber o mesmo. No entanto, se os avós tiverem mais do que um neto e tomarem conta apenas do que vive mais próximo, o critério aceite é o da conjugação da necessidade com a proximidade.

Estas conclusóes são semelhantes às de Jacques Godbout na sua reflexão sobre a aplicação das normas de justiça às relaçóes de parentesco (Godbout, 1995). O autor analisa três circuitos de troca distintos - a ajuda em serviços, os presentes e a hospitalidade - e conclui que os critérios que regulam cada um deles são distintos. Godbout chega a uma conclusão 
final, para a qual também aponto: a norma da justiça é de difícil aplicação no interior da rede de parentesco. Ela apenas constitui um princípio dominante quando aplicada à comparação entre diferentes retribuiçôes para uma mesma contribuição. Ou seja, o princípio náo se aplica entre um dador e um receptor, mas entre dadores ou entre receptores. Como afirma Godbout, nas redes de parentesco a ideia de justiça náo diz directamente respeito à relação contribuição-retribuição, mas à comparação entre "pares" (dadores ou receptores) na sua relação com um terceiro (1995: 361).

A análise das normas no interior das redes mostra que estas obedecem aos princípios gerais do sistema de dádiva. A minha pesquisa demonstra a permanência e vitalidade do dom e a sua importância na produção de bem-estar das famílias, contrariando a ideia generalizada de que a dádiva desapareceu das sociedades contemporâneas e cedeu o seu lugar ao cálculo racional e à troca mercantil.

$\mathrm{O}$ pensamento dominante defende que à medida que o individualismo ganha peso, a generosidade se perde e é substituída pelo cálculo egoísta. Se, por um lado, se lamenta estas tendências, por outro, valoriza-se algumas das conquistas: o Estado-Providência apresenta-se como um substituto feliz da dádiva: ninguém se lamenta que a esmola e a caridade sejam substituídas por um sistema mais justo de segurança social. Se as sociedades contemporâneas resistem a acreditar na existência do dom é porque o representam como a imagem contrária do interesse material e egoísta: a "verdadeira" dádiva é gratuita; como a gratuitidade é impossível, a verdadeira dádiva é impossível.

Marcel Mauss, em Ensaio sobre a Dádiva (1988), afirmou a centralidade da dádiva nas sociedades arcaicas. No entanto, teve dificuldade em reconhecer que a sua existência nas sociedades modernas fosse além do estatuto de manifestação residual do passado. Penso, no entanto, tal como os autores do M.A.U.S.S. ${ }^{12}$, que "o dom é tẫo moderno e contemporâneo como característico das sociedades arcaicas” (Godbout, 1992: 20). Fenómenos como a oferta de prendas, a prestação de cuidados às crianças, aos idosos e aos doentes, os convites para festas e a hospitalidade, o voluntariado, a doação de sangue e de orgãos constituem formas de troca social que não são hoje residuais nem quantitativamente (dada a sua frequência no quotidiano) nem qualitativamente (dada a sua importância na vida dos indivíduos). Adopto a definição de dádiva proposta por Godbout em L' Esprit du don (1992), e que Caillé retoma (2000): "toda a prestação de bem ou serviço efectuada sem garantia de retorno, com vista a criar, alimentar ou recriar o vínculo social entre as pessoas"

12 O movimento M.A.U.S.S. - Moviment Anti-Utilitariste en Sciences Sociales - fundado em 1981, tem, como explica Alain Caillé, na sua apresentação ao público brasileiro, "um sentido negativo e outro positivo". O sentido negativo prende-se com a recusa do utilitarismo, a ideologia hegemónica da modernidade. O sentido positivo procura a reflexâo, a partir das ideias de Marcel Mauss sobre o dom (Caillé, 2003:16). O Movimento, que surgiu como reacção à hegemonia do economicismo nas ciências sociais que se instalara durante a década de 70, publica actualmente a Revue du MAUSS e reune uma série de investigadores de áreas diversas. Os autores do M.A.U.S.S. rejeitaram os raciocínios dominantes, recusando-se a aceitar o homo economicus como concepção do indivíduo e o mercado como princípio estruturador da sociedade. Deste modo, procuraram argumentos que lhes permitissem construir uma visão alternativa do mundo. Esses argumentos foram-lhes dados pela obra de Marcel Mauss, sobretudo pelas ideias contidas no Ensaio sobre a Dádiva. Esta obra contém a "descoberta” (a designação é de Caillé) crucial para o movimento: a de uma certa universalidade, nas sociedades arcaicas, da tríplice obrigação de dar, receber e retribuir. O dom apresenta-se, para Mauss, como um "fenómeno social total". Mesmo efectuada por indivíduos singulares, a dádiva diz respeito ao conjunto das dimensóes da acção e repercute-se em toda a sociedade. Para além da sua dimensão utilitária, ela é, essencialmente, simbólica. Não só os dons são símbolos, como os símbolos devem ser entendidos como dons. Deste modo, "o paradigma do dom pode ser compreendido igualmente como um paradigma do simbolismo” (Caillé, 2000: 125). 
(Caillé, 2000: 124; Godbout, 1992: 32). O trabalho que tenho vindo a realizar mostra como o dom, assim caracterizado, como modo de circulação dos bens ao serviço do laço social, constitui um elemento essencial da sociedade.

A perenidade da dádiva não resulta apenas da necessidade de trazer um "suplemento de alma" aos interesses mercantis e estatais, mas testemunha o "facto de o dom, ele próprio, tal como o mercado e o Estado, formar um sistema" (Godbout, 1992: 21), sistema de relaçóes sociais, propriamente ditas, enquanto relaçôes não redutíveis a interesses económicos ou de poder.

O facto de o dom ser diferente da troca mercantil não implica que seja gratuito. É verdade que "o dom gratuito não existe" (Bourdieu, 1997: 124), o dom serve para estabelecer relaçôes; uma relação sem esperança de retorno, uma relação de sentido único, não é uma relação. Mas o dom também não se reduz à expectativa de retribuição, tal como a corrente utilitarista defende: "os móbiles do dom estão relacionados entre si de uma maneira profundamente paradoxal” (Caillé, 2000: 10). Interesse e desinteresse, liberdade e obrigação alimentam a dádiva e o vínculo social que ela estabelece. Se a regra fundamental é a reciprocidade, ela não se processa numa lógica binária de dádiva e retribuição. Ao aceitar uma dádiva - "muito obrigado" - o receptor passa a ter obrigaçóes para com o dador. O dom instala entre os parceiros um estado de dívida que se torna permanente à medida que se constrói um ciclo de dom e contra-dom. Ao contrário do mercado que se rege pela anulação da dívida, a dádiva funda-se sobre ela (Godbout, 2000).

O conceito de dívida positiva utilizado por Godbout (2000) revela-se mais produtivo para analisar a circulação da dádiva no interior da família do que o de reciprocidade. Numa relação, o estado de dívida positiva escapa à equivalência e faz com que cada um considere que recebe mais do que dá, embora esteja sempre disposto a retribuir. A definição de Godbout é bastante frutífera para perceber o dom familiar, e, sobretudo, os fluxos intergeracionais: "a dívida positiva existe quando o receptor não percebe no dador a intenção de o endividar através do seu gesto - o que está estreitamente ligado ao prazer de estar em dívida, elemento essencial do estado de dívida positiva" (Godbout, 2000: 47). Esta condição marca o discurso da maior parte das pessoas entrevistadas - dívida é a palavra mais usada para se falar das dádivas dos progenitores. Por um lado, eles deram a própria vida, e essa é por si uma dádiva impossível de retribuir - embora os netos sejam por vezes encarados pelos filhos como uma recompensa dada aos pais pelos seus sacríficios. ${ }^{13}$ Por outro lado, existe a noção de que é necessário retribuir de algum modo, mas que qualquer retribuição "nunca paga” o que já se recebeu. Finalmente, como já o mostraram outros estudos (Degenne e Lebeaux, 1997), existe quase um consenso sobre a inexistência de expectativas por parte dos pais dadores face a uma retribuição dos seus filhos - como diz uma entrevistada, "eles [os pais] gostam muito mais de nos ajudar a nós do que nós os ajudarmos a eles".

A dívida com os progenitores é simultaneamente uma dívida económica e uma dívida de reconhecimento. Elementos materiais, afectivos e simbólicos misturam-se num jogo complexo que, no entanto, não deixa totalmente de lado a reciprocidade. Se o parentesco mantém a reciprocidade "à distância”, como diz Godbout, ele não a exclui definitivamente, antes a reveste de formas diversas: ela é "limitada" (Godbout, 2000: 36), "diferida"

${ }^{13}$ Deste modo, a continuidade da filiação inscreve-se no circuito amplo e no tempo longo da dádiva familiar, e é, sem dúvida, uma das formas mais claras do modo como os laços de parentesco tornam equivalente o incomensurável. 
(Bawin-Legros, 2003: 169), “indirecta” (Attias-Donfut et al., 2002: 263). Na reciprocidade familiar, por um lado, dádiva e retribuição fazem circular e equivaler coisas muitos diferentes; por outro lado, entre dom e contra-dom, o tempo pode correr sem que o ciclo se quebre.

Não conta o que se troca, nem quando se troca. Nesta dádiva, o tempo conta tanto menos quanto mais se confia no outro. Mediada pela afectividade e pela confiança, a reciprocidade entre parentes realiza-se muitas vezes à "escala de uma vida" e transforma a ajuda numa espécie de "crédito a longo prazo" que não necessita de ser retribuída no imediato, nem de ser simétrica: o contra-dom pode vir muito mais tarde ou mesmo ser destinado a outra pessoa (Bawin-Legros, 2003; Déchaux, 1990; Finch,1989). Nesta concepção inscreve-se também uma ideia clara da evolução das posiçóes de receptor e de dador ao longo da vida, de pais e filhos. Na infância e juventude, os filhos são apenas receptores, na idade adulta são receptores e dadores, de uma forma assimétrica, até que os pais atingem a velhice, e nessa altura passam eles a ser os receptores. A velhice dos pais é a altura em que a norma implícita da reciprocidade é posta em prática (Bawin-Legros, 2003; Grundy, 2005; Schaber, 1995).

Os cuidados dos idosos são um exemplo de como na dádiva familiar a norma da reciprocidade se estende no tempo longo da história familiar e vai para além da troca restrita. Cuidar dos pais na velhice não é apenas uma retribuição pelas dádivas recebidas no decorrer da vida, é também uma retribuição pelas dádivas que estes fizeram aos seus próprios pais. Deste modo, o mesmo tipo de dom pode ter diferentes actores envolvidos no momento da dádiva e no momento da retribuição. Como diz um entrevistado: "eles também tomaram conta de mim, e se um dia eu quero que alguém tome conta de mim também tenho que tomar agora conta de alguém, é simples". Filhos, pais e avós fazem parte de uma cadeia intergeracional, através da qual a dádiva circula e a reciprocidade chega sempre um dia (Attias-Donfut et al., 2002).

É necessário pensar a dádiva não como uma série de actos unilaterais e descontínuos, mas como relação: "o dom não é uma coisa mas uma relação social” (Godbout, 1992: 15). A expectativa de retribuição e a retribuição estão sempre presentes; no entanto, tendem a ser ocultadas - "muito obrigado"; "não é nada". Não só se escondem as verdadeiras regras como se enunciam outras que tendem a negar a lógica existente ${ }^{14}$. Esta foi uma das observaçóes que Mauss fez para as sociedades arcaicas: onde o investigador vê interesse e obrigação, o discurso dos actores é o da voluntariedade e generosidade. A relação do dom com as regras afasta-o do paradigma holista (tal como do modelo individualista). Na realidade os elementos de um sistema de dádiva têm uma relaçáo particular com as regras. Em primeiro lugar, "as regras do dom devem ser implícitas" (Godbout, 2000: 159). Em segundo lugar, existe uma tendência generalizada para os actores negarem a obediência a um sistema de regras num gesto de dádiva. A "verdadeira” dádiva é aquela que não tem como objectivo conformar-se com uma convenção social ou uma regra, mas sim exprimir o laço com o outro.

Deste modo, a tendência é de negar a importância do próprio dom (Godbout, 2000: 159). O dever da reciprocidade não é nomeado de modo a conservar um risco no contra-dom, uma incerteza e indeterminação. O doador age deste modo para ficar o mais longe possível do compromisso contratual que tem a propriedade de obrigar o outro,

14 Bourdieu fala de "tabu da explicitação" (1997: 124). 
independentemente dos seus sentimentos. O objectivo é deixar o outro livre de retribuir ou não, de "calcular" o que deve retribuir, quando o deve fazer, etc., de modo a "obrigar mas livremente" (Godbout, 1992: 264).

Assim, uma das características fundamentais da dádiva é o seu carácter simultaneamente livre e obrigatório. Os interlocutores são simultaneamente livres e constrangidos a dar, receber e retribuir. A relação de dom estabelece-se a partir duma situação onde nada existe a não ser indivíduos separados que, enquanto tal, seguem apenas o seu próprio interesse. Quando surge uma dádiva cria-se um sentimento de obrigaçáo, o indivíduo é livre para o assumir ou para o recusar, recorrendo, por exemplo, a um contra-dom monetário que recoloca a situação no ponto de partida. Ao assumir a obrigação de retribuir estabelece-se uma relação, no interior da qual a dádiva circula como forma de alimentar e recriar o vínculo estabelecido.

A natureza do vínculo social criado pela dádiva moderna parece, pois, ser distinta da do dom arcaico. Nas sociedades contemporâneas, a dádiva cria um vínculo social de solidariedade selectiva, construída com base em princípios de afectividade e afinidade, que se encontram em permanente construção e reconstrução. Fora da rigidez relacional e espacial das sociedades arcaicas, os indivíduos possuem uma autonomia maior na escolha dos seus círculos de pertença e na definição das suas obrigaçóes práticas e morais. Deste ponto de vista, o dom moderno é muito mais livre que o dom arcaico.

A tríplice obrigação "dar, receber, retribuir" estrutura as práticas e representaçôes dos actores, mas dela decorrem diversos problemas para a acção das redes sociais (Portugal, 2007). A pesquisa empírica revela a relação entre normas e laços e a especificidade dos laços de parentesco no interior da rede. Mostra, também, a complexidade de que se reveste a aplicação das normas no interior das redes. A análise das normas exige a diferenciação do parentesco dos restantes laços, mas obriga, também, a um olhar atento sobre o modo como se constroem e aplicam os princípios reguladores da dádiva familiar.

As interacçôes e as trocas obedecem a um modelo complexo, cujos princípios são, muitas vezes, contraditórios entre si e geradores de tensóes e conflitos. A dependência dos apoios que fluem nas redes choca com o princípio basilar da autonomia; os sentimentos de dever e de obrigação conflituam com a liberdade e a afectividade; a norma da reciprocidade ilude a assimetria das trocas; o dom coexiste com o interesse utilitário; o princípio da igualdade é obscurecido pelas desigualdades sociais e sexuais que marcam as ajudas.

Este conjunto de paradoxos deve ser olhado a partir de dois eixos fundamentais de problematização: a diferenciação do parentesco dos restantes laços e o confronto entre práticas e representaçóes. $\mathrm{O}$ trabalho empírico mostra que as normas têm uma aplicação diferenciada dentro e fora dos laços de família. As redes definem formas de inclusão e de exclusão, oferecem protecção ou indiferença, a partir de critérios de confiança e de desconfiança. As entrevistas mostram que o parentesco biológico oferece aos indivíduos a segurança que os outros laços náo comportam, ao mesmo tempo que impóe deveres e obrigaçóes claras.

Deste modo, no processo de individualização da contemporaneidade, a fragilização do laço conjugal (Singly, 2001) e do laço profissional (Sennett, 2001) não vão de par com a fragilizaçáo do laço de parentesco. O papel e a normatividade das relaçôes familiares revelam-se de múltiplas formas na pesquisa que realizei, permitindo afirmar a sua vitalidade e importância na configuração das redes sociais. Se como afirma Martuccelli, "o indivíduo existe apenas na medida em que é sustentado por um conjunto de suportes" (2002: 63), a minha pesquisa mostra que os laços de parentesco são um suporte fundamental. 
A análise das normas, no interior das redes, mostra que o parentesco tem propriedades alquímicas: torna equivalente o que não o é; permite a dependência sem perder a autonomia; concilia liberdade e obrigação; transforma a dívida num elemento positivo. Esta alquimia é possível graças ao predomínio do sistema de dádiva e ao primado do laço social sobre as coisas, na definição das relaçôes entre os indivíduos.

Tudo isto não se faz, contudo, sem problemas. A definição e a aplicação das normas têm, muitas vezes, uma dimensão conflitual, mais ou menos explícita. As tensóes, no interior da família, são, frequentemente, silenciadas, ou expressas através de não-ditos, gerando mal-estar. Outras vezes, são assumidas com veemência, gerando incompatibilidades e rupturas nos relacionamentos.

Outra dimensão relevante da dádiva familiar é a forma como reproduz, de um modo muito claro, desigualdades sociais e sexuais. Por um lado, a obrigação de reciprocidade directa aumenta nas famílias pertencentes a grupos socioeconómicos mais desfavorecidos. Por outro lado, o dever de "cuidar dos seus" inscreve-se nas representaçóes de todos, mas, sobretudo, nas práticas das mulheres.

\section{Consideraçóes finais}

A análise das normas que regulam a acção das redes mostrou que existe nas famílias um enorme potencial de solidariedade que é necessário pensar para definir o seu lugar na produção de bem-estar. O "familismo moral" que identifiquei nas redes revela-se importante pela sua dimensão de recurso estratégico, mas também pelas suas potencialidades para pensar o laço social. O "familismo moral" não se fecha ao outro, pelo contrário disponibiliza para a relação, tece obrigaçôes, assenta na confiança tecida nas relaçôes interpessoais. Deste modo, coloca um desafio à discussão das relaçóes entre público e privado.

Este tipo de laços, que estrutura as redes socias, pode dar azo a relaçóes baseadas na horizontalidade ou na verticalidade. As análises, nos países do Sul da Europa, têm destacado a dimensão vertical e a assimetria, sublinhando a importância do clientelismo e do particularismo no acesso aos recursos (Mutti, 2000; Ruivo, 2000; Santos, 1994). Mas as relações baseadas na dádiva podem, também, ser geradoras de relaçóes horizontais de associação ${ }^{15}$. Nesta dicotomia reside o lugar da família na realização do laço político. O seu papel dissociativo ou associativo joga-se na sua relaçáo com outros espaços estruturais, nomeadamente na relação com o espaço da cidadania.

As análises de Boaventura Sousa Santos sobre a relação entre Estado e sociedade civil em Portugal (Santos, 1994 e 2000) identificaram uma oscilação entre um Estado protector e um Estado predador, que constrói uma sociedade civil íntima e uma sociedade civil estranha, afastando os cidadãos que não possuem relaçóes interpessoais privilegiadas no interior do sistema administrativo. Este tipo de processos conduziu à desconfiança profunda face à capacidade protectora do Estado e contribuiu, sem dúvida, para um centramento no espaço doméstico.

Deste modo, urge pensar soluçóes alternativas para um modelo cada vez mais sujeito a pressóes. Do meu ponto de vista, a perspectiva a partir das redes sociais e da dádiva pode contribuir para a construção dessas soluçóes. O pensamento a partir destes dois paradig-

15 Como mostram os trabalhos de Paulo Henrique Martins. Cf. o Capítulo 1 deste livro e Martins (2004). 
mas permite integrar diferentes níveis analíticos e de acção, possibilitando uma reinvenção do político, sobretudo a capacidade de o pensar fora dos limites do Estado. O paradigma da dádiva impóe o princípio da pluralidade de lógicas na construção da interacção social e da ambivalência estrutural das práticas sociais que se revelam na experiência concreta da definição dos laços sociais. A perspectiva a partir das redes permite integrar uma dimensão tradicional e uma dimensão progressista, conjugando particularismo e universalismo. Oferece, deste modo, um potencial que importa discutir e valorizar.

\section{Referências bibliográficas}

ANDREOTTI, Alberta et al. - "Does a Southern European Model Exist?". Journal of European Area Studies. vol. 9, $\mathrm{n}^{\circ} 1,2001$, pp. 43-62.

ATTIAS-DONFUT, Claudine; LAPIERRE, Nicole; SEGALEN, Martine (2002), Le nouvel esprit de famille, Paris, Éditions Odile Jacob.

BANFIELD, Edward C. - The Moral Basis of a Backward Society. Nova Iorque: The Free Press, 1967.

BAWIN-LEGROS, Bernadette - Le nouvel ordre sentimental. À quoi sert la famille aujourd'hui? Paris: Payot, 2003.

BOURDIEU, Pierre - Razóes Práticas. Sobre a teoria da acção. Oeiras: Celta, 1997.

CABRAL, Manuel Villaverde - "Autoritarismo de Estado e sociedade civil real em Portugal", Comunicação ao Colóquio Internacional "Acção Colectiva, Espaço Público e Cidadania", Coimbra, 6 e 7 de Janeiro de 2005. (policopiado)

CAILLÉ, Alain - "Dádiva, cidadania e democracia". In MEDEIROS, Alzira; MARTINS, Paulo Henrique (orgs.), Economia popular e solidária. Desafios teóricos e práticos. Recife: Ediçōes Bagaço, 2003, pp.16-25.

CAILLÉ, Alain - Anthropologie du don. Le tiers paradigme. Paris: Desclée de Brouwer, 2000.

COENEN-HUNTER, Josette; KELLERHALS, Jean; von ALLMEN, Malik - Les réseaux de solidarité dans la famille. Lausanne: Éditions Réalités Sociales, 1994.

DÉCHAUX, Jean-Hugues - "Des relations de parenté inédites?”. Esprit. 1990, pp. 91-101.

DEGENNE, Alain; FORSÉ, Michel - Les résaux sociaux. Paris: Armand Colin, 1994.

ESTANQUE, Elísio; MENDES, José Manuel - Classes e desigualdades sociais em Portugal. Um estudo comparativo. Porto: Afrontamento, 1998.

FERRAND, Alexis - "Les réseaux de relations personnelles". Actes du Séminaire "Du politique et du social dans l'avenir de la famille". Paris: La Documentation Française, 1992, pp. 79-90.

FINCH, Janet - Family Obligations and Social Change. Cambridge: Polity Press, 1989.

FISCHER, Claude S. - To Dwell Among Friends. Personal Networks in Town and City. Chicago and London: The University of Chicago Press, 1982.

FONTES, Breno - "Capital social e terceiro sector: sobre a estruturaçáo das redes sociais em associaçôes voluntárias". In Paulo Henrique Martins; Breno Fontes (orgs.), Redes Sociais e saúde: novas possibilidades teóricas, Recife: Editora Universitária da UFPE, 2004, pp. 49-75.

GODBOUT, Jacques T. - L’esprit du don. Paris: Éditions La Découverte, 1992.

GODBOUT, Jacques T. - "La norme de justice dans les relations de parenté". L’Année Sociologique. vol. 45, n², 1995, pp. 351-370.

GODBOUT, Jacques T. - Le don, la dette et l'identité. Paris: La Découverte, 2000.

GRUNDY, Emily - "Reciprocity in Relationships: Socio-economic and Health Influences on Intergenerational Exchanges Between Third Age Parents and their Adult Children in Great Britain". British Journal of Sociology. vol. 56, $\mathrm{n}^{\mathrm{o}} 2,2005$.

HESPANHA, António Manuel - "Carne de uma só carne: para uma compreensão dos fundamentos histórico-antropológicos da família na época moderna”. Análise Social. 123-124, 1993, pp. 951-973.

KELLERHALS, Jean; COENEN-HUTHER, Josette; MODAK, Marianne - Figures de l'équité. La construction des normes de justice dans les groupes. Paris: PUF, 1988.

KELLERHALS, Jean; MODAK, Marianne; SARDI, Massimo - "Justice, sens de la responsabilité et relations sociales". L'Année Sociologique. Vol. 45, n², 1995, pp. 317-349.

LÉVI-STRAUSS, Claude - Les structures élémentaires de la parenté. Paris: PUF, 1949.

LIN, Nan - Social Capital. A Theory of Social Structure and Action. Cambridge: Cambridge University Press, 2001. 
MARTINS, Paulo Henrique - "A dádiva e a sua importância teórica para se pensar as relaçōes entre Estado, mercado e comunidade". Comunicaçáo Apresentada ao VIII Congresso Luso-Afro-Brasileiro de Ciências Sociais, Coimbra: Setembro de 2004. (policopiado)

MARTUCCELLI, Danilo - Grammaires de l'individu. Paris: Gallimard, 2002.

MAUSS, Marcel - Ensaio sobre a dádiva. Lisboa: Ediçôes 70, 1988.

MILARDO, Robert - "Families and Social Networks: An Overview of Theory and Methodology". In Robert Milardo (ed), Families and Social Networks. Newbury Park: Sage, 1988, pp. 13-47.

MUTTI, Antonio - "Particularism and the Modernization Process in Southern Italy". International Sociology. vol. 15 (4), 2000, pp. 579-590.

O’NEILL, Brian Juan - Proprietários, lavradores e jornaleiras. Desigualdade social numa aldeia transmontana, 1870-1978. Lisboa: D. Quixote, 1984.

PORTUGAL, Sílvia - "O que faz mover as redes sociais? Uma análise das normas e dos laços". Revista Crítica de Ciências Sociais. no 79, 2007.

PORTUGAL, Sílvia - Novas Famílias, Modos Antigos. As redes sociais na produção de bem-estar. Coimbra: Faculdade de Economia da Universidade de Coimbra. Tese de Doutoramento em Sociologia, 2006.

RUIVO, Fernando - O Estado labiríntico. O poder relacional entre poderes local e central em Portugal. Porto: Afrontamento, 2000.

SANTOS, Boaventura de Sousa - Pela mão de Alice. O social e o político na pós-modernidade. Porto: Ediçóes Afrontamento, 1994

SANTOS, Boaventura de Sousa - A crítica da razâo indolente. Contra o desperdício da experiência. Porto: Ediçốes Afrontamento, 2000.

SCHABER, Gaston - "Don de temps, don d'argent, don d'espace". In Claudine Attias-Donfut (org.) Solidarités entre générations. Vieillesse, familles, État. Paris: Nathan, 1995, pp. 97-115.

SENNETT, Richard - A corrosão do carácter. Lisboa: Terramar, 2001.

SINGLY, François de - "La naissance de l'individu individualisé et ses effets sur la vie conjugale et familiale". In François de Singly (Dir.) Etre soi parmi les autres. Paris: L'Harmattan, 2001, pp. 5-14.

SMART, Carol; SHIPMAN, Beccy - "Visions in Monochrome: Families, Marriage and the Individualization Thesis". British Journal of Sociology. vol 55 (4), 2004.

SMITH-LOVIN, Lynn; MCPHERSON, J. Miller - "You Are Who You Know: A Network Approach to Gender". In Paula England (ed.), Theory on Gender-Feminism on Theory. New York: A. de Gruyter, 1993, pp. 223-251. 